\title{
The Development Situation of Chinese National Music Teaching
}

\author{
Nan Song \\ Xi'an Conservatory of Music, Xi'an, Shaanxi Province, China \\ 36639341@qq.com
}

Keywords: Chinese national music, music teaching, development and status

\begin{abstract}
Chinese national music has a long and profound history, accumulated in the course of history, development and change. But Chinese national music teaching mode has some deficiencies, to a certain extent, restricting the development of folk art, the folk music teaching faces bigger challenges. This article mainly discusses the national music teaching at present, and the reform measures of national music development.
\end{abstract}

\section{Introduction}

Chinese national music has always been in the inheritance and development, promoting the inheritance in the development. The history of music in China can be traced back thousands of years ago, far longer than the founding of the history of western countries. Western music also has been integrated into the Chinese music elements, they said, of twelve-tone used piano are China's Ming dynasty Ming Jing's invention, but now we can hear whether the traditional music can reproduce the appearance of one hundred years ago are questionable, the reason is because the notation is not perfect in our country, the inheritance of music is implemented under the form of artists, and every generation successor will always own thought and creativity to join in the work, it formed the development type of inheritance, which we now it is difficult to exactly understand the beauty of the traditional music [1]. This is Chinese characteristics of Chinese national music turned on. I think traditional is the predecessors of cultural legacy, so we took this heritage, after "carefully", make it "value-added", and then left to future generations. For future generations, we give them is traditional, and not just the ancients left behind is the tradition. This makes the national music in developing its forever; this is kind of energetic inheritance [1]. Any development is inseparable from the characteristics of The Times, in an environment of today, we are in the world mainstream music, not affected by it, another a way to develop Chinese national music could not be achieved.

\section{The status quo of Chinese national music teaching}

Chinese national music is generally divided into song, singing and dancing music, hip-hop music, opera music and instrumental music five categories. Songs can be divided into ancient songs and folk songs; Folk songs and tonality, folk songs, minor, and long songs and multi part different genres; With folk songs, and due to the difference of regional, national and different styles, each has its characteristics [1]. China's traditional folk musical instrument has experienced thousands of years of development history, once owned more than 500 kinds of Musical Instruments, however, can keep so far but dozens of. Methods according to its playing and performance can be divided into wind instruments, instrument, stringed instrument and percussion four categories, these instruments can be both a solo, and can be combined into various forms and the band for repetition and ensemble, and has a unique and rich artistic expression, national instrumental music with all kinds of Musical Instruments solo, repetition and ensemble.

Most ethnic Musical Instruments are way, adopting the teaching and learning instruments need to be hold, spread and popularization for instruments was limited. In the context of the Chinese nation 
five thousand years of history, because of this or that many instruments are lost, before more than most of the instruments used in civil weddings, in recent years, along with the development of the culture of folk music in addition to the national musical instrument ensemble, widely spread in the professional colleges and universities, combined with music lovers and professional support, make the Chinese national Musical Instruments to achieve an unprecedented period of prosperity [1]. But folk music teaching mode has some deficiencies, to some extent, restricted the development of folk art. And it caused the teaching model reform calls for four major challenges facing the current folk music teaching:

The elements impact of pop music. With the rapid development of modern society and commodity economy, people's values change, the young generation due to the star effect is more and more attention and affection to the pop music, national music survival plight is more and more obvious, the survival of the space is shrinking. Some traditional ethnic music in People's Daily life rarely seen living existence, leading to progressive loss of many species of precious folk art, die, if left unchecked, will no doubt give people bring great disaster [2]. In this environment, the pure theoretical teaching cannot let students experience and understand the national music and the beauty of the soul can't make the music professional college students become national traditional music teaching and protector, this is the biggest obstacle in national music heritage.

The teaching mode of national instrumental music. Education means increasingly update today's defects are revealed. Teachers' teaching activities is to for many years engaged in the artistic performance experience, teach students the theoretical summary and neglect for related experience [2]. This makes the students get into the framework of the set to the teachers' personal experience, difficult to form artistic style.

Traditional folk music teaching activities will regard skill as the key. Skill as training center, and ignore the content of the teaching mode is the thinking mode of Chinese folk music teaching has always been. Modern education mode, the folk music teaching should not only train students master performance skills, also need their understanding of related music theory to know there is enough, to be able to combine playing skill and music knowledge closely [2]. Cause this phenomenon is rooted in Chinese traditional culture is to music education as a technical education, have do not take the music education theory. For musicians to play a musical instrument, play only skilled work, forget the condition by heart, gratitude sorrows.

\section{The method of national music teaching reform}

Correct positioning of national folk music. Chinese national folk music, spectacular time span is big, regional wide cross. Folk music as a kind of ethnology, it is a cross subject of ethnology and musicology, mainly adopt the method of field investigation to a social science that studies law of evolution of national development. Traditional Chinese national folk music is different from other music research, it is a practical subject, need a combination of theory and practice, it exist today some of the theories and methods are also senior music experts in a large number of field practice and the adaptation of innovation to sum up gradually [3]. While China of folk music curriculum reform in colleges and universities through the theory with practice, must be able to push Chinese traditional music subject research into to a new stage of historical development. Concrete can be through the following several ways:

1) Play the role of national music artists. Folk music is due to the generation of folk artists, to carry forward, these folk artists in this process, has played an indelible role. Adaptation of these artists in the creation process, the "pursuit", of the Chinese music seriously draw all kinds of nutritious elements, created a lot of music works with national characteristics and national spirit, to develop extensive and profound culture of folk music..

2) Combination of traditional folk music and pop. Folk music has a long history.It is the foundation of other music, which laid a foundation for the formation of other music [3]. Every song folk music contains the national customs, psychological quality and aesthetic temperament and interest, and today's pop music is also in line with the current characteristics of keeping pace with the Times, living custom and the change of living environment lead to the younger generation now prefer 
pop music, has a certain times, but no time feeling something even if again good also will eventually be replaced. China's folk music has a strong national character, pop music to get long-term development, must take folk music as fundamental, according to age characteristics at the same time, can change to create better works of music. If you want to make the folk culture of China has a long history development, which requires our contemporary some musicians is not only a simple adaptation, imitation is also adapted to some of the music into their characteristics for creation, to make young people can be in the acceptable range to better absorb the essence of folk music, feel the endless charm of it.

3) Vigorously promote national folk music. Appeared with the development of modern society, many "make track for a star" crowd, star has been in the life of people occupies a more important position. If it is right to use the "star effect", the development of national folk music plays a considerable role [3]. The pop singer is the adaptation of folk music in at the same time, to satisfy his creation also stimulated the enthusiasm of folk songs of the younger generation.

4) Introduce the national folk music culture resources; highlight the school characteristics play a role of carrier. China's higher education in the great rejuvenation of the Chinese nation on the road, assuming the historic task of personnel training in an increasingly international, popularization and mercerization of social development environment, higher education internationalization means that China's higher education structure and quality of a corresponding shift;China's higher education is faced with many new opportunities and challenges, as the popularity of the market, China's higher education level also become diversified and more hierarchical [4]. But one primary problem of Chinese universities is the diversity of characteristics on decline, even no features, to student's education also is scripted, school size is bigger and bigger, but in the original characteristic gradually disappear, school characteristics of colleges and universities into a dilemma. This requires that universities must constantly look for breakthrough, as a kind of special music, folk music colleges and universities according to the local characteristics, establishing education demonstration base.

\section{The reform of the national folk music courses}

China national folk music course in college music professional values of reason is various, both the social environment such as commercial, recreational pop music occupies the absolute superiority in music life, has a huge impact on national music the objective factors, there is also a course itself is not adapt to the current education development and the need to reform the subjective factors. Focus on the subjective factors in the teaching of the breach, explore a effective way to teaching reform of national folk music, draw the students into ethnic music class, make them fully appreciate the motherland the unique charm of folk music, cultivate their love of national music, is a normal music education bounden responsibility.

Reasonable arrangement of courses. The arrangement of the music curriculum for students of colleges and universities curriculum ability absorption has a very important role. First of all, in the process of teaching in colleges and universities, should be reasonable arrangement of curriculum Settings. Folk songs are the foundation of the folk music, folk music for several other class form laid a solid foundation. In course teaching of folk music, should with folk songs as the interpretation of the theme, then with the folk music the five classifications in the other four categories of opera music, general outline of rap music, song and dance appreciation, Chinese national instrumental music. After let the student have a systemic understanding for knowledge, and some typical films is put in to students, which makes students better to absorb knowledge [4]. At the same time, school should arrange some practical courses, organize students to go out to tour, can understand and experience the various national and regional customs, different nationalities, and different customs, ethnic music style is different.

School music education development of heritage plays an important role in the national folk music in China, the school music education to popularize knowledge of some Chinese national folk music, let the student like folk music, let them appreciate national folk music, and enjoy at the same time, be able to use his own emotional and cognitive experience and understanding, through such education, let people to know more about folk music, classical music, the national cultural heritage better [4]. 
Finally, combining traditional and popular, in the modern some of the new folk song to add some new elements, ethnic Musical Instruments and digital band together into the creation of national music, it is also in the new era, new era under the social background of the development direction of national music.

Cultivate and develop the students' ability of thinking in images. Along with the development of science and technology changes with each passing day, the multimedia era, we should use for a more intuitive, three-dimensional network multimedia teaching. Network multimedia teaching can be more intuitive understanding of learning content, to better absorb the interpretation of the contents of the classroom. At the same time, if the use of the network multimedia broadcast a Guzheng playing video, can more intuitive understanding of the Chinese zither [5]. Not only that, but the school shall establish a series of network teaching platform to learn, did not understand something in class, class video upload through the school teachers, teaching plans, such as material, lets the student study independently, can at any time and students can also see other teachers' class video on the Internet, let the students can be more benefit.

To make students know more about China's outstanding national folk music, stimulates the student to love the motherland of the art of music feeling and sense of national pride and self-confidence, can use "please come in" mode of teaching in colleges and universities, the folk artists please go to the folk music of our university's class, feeling folk song style, cultivate interest [5]. In each primary school of textbooks is income a lot of excellent folk songs, in the teaching, to very pay attention to the use of a variety of means, let the student feel fully style characteristic and function of various kinds of genre of folk songs. "' going out "is our college students go to the people, and the local folk artists experience life together, with the local folk musician communicate with each other, learn from each other, experience the charm of folk art, the national folk music into his mind.

Usage of local resources plays the role of education training. First of all, should take advantage of local resources, attracting outstanding social folk talents, improve the faculty, better let exhibition national folk music teaching in colleges and universities. Every region and nationality has its own unique regional culture, in the folk music teaching in colleges and universities, can improve the teaching according to the unique regional, even can build regional education demonstration, this kind of education as a kind of resources and local characteristics [6]. At the same time, through the recruitment, absorb the society or the local folk old actor to ecological teaching school, rather than merely limits and textbooks. So we for the Chinese native place has a deeper cognition folk characteristics, features, image to record the value of the local folk music, do a good job in education and the role of inheriting adequately.

At the same time, to seek for the traditional culture inheritance education teaching method, so the traditional music teaching content can be enriched and expanded further. Students out of the classroom, in the society, to the folk, into the field, so that the students can study in this environment, access to the more traditional folk culture, enhance the level of academic theory research and play a major influence on the development of students in the future. Students only learn from the society, to learn from folk artists, art practice class can truly will be implemented to use.

Teachers improve their professional level in the daily work. To make college students better understand and study folk music, the teacher in perfecting their knowledge at the same time, should also be further folk, a more profound feeling the charm of folk music [6]. The teacher only has sufficient theoretical knowledge and practical experience, in the process of lead to the student ability, will not lead to a little knowledge of students.

First of all, college students should make efforts to improve their practical ability. Place for Chinese colleges and universities to carry out the music is to train professional artists, the course of colleges and universities to carry out the national folk music course of the Chinese national folk music has a very important role. Produce various national professional music talents to the regional colleges and universities and primary and secondary schools to teach, to inherit the traditional folk music of the Chinese nation and carry forward the national folk music art, prepared plenty of reserve forces [6]. National folk music is a practical course, this requires the school shall establish demonstration base, take the student to tour the field, feeling and the study of folk music, at the same 
time of student learning theory knowledge, practice education, deepen students' understanding of the national folk music and learning, cultivate the students' cognitive ability.

Second, college students should use their advantages, professional fields spread in society. College students' learning ability is strong, through the school during the study of folk music that make the change the cognition of folk music. Learned from previous fuzzy understanding, from don't like to listen to. On the understanding of national folk music culture changes will affect them slowly around the relatives, friends or colleagues for some time.

\section{Conclusion}

Chinese national music is a yuan of species in the world of multiple music culture resources, it has its own unique position, function and value, has its survival soil and the rationality and necessity of continued development in certain period of time. National music can also enhance national cohesion. All ethnic groups of different music culture has greatly enriched the world cultural resources, so as to make the world cultural profusion much appearance, bright. Era in the development, in advance, the idea of people changes in thinking and life rhythm, people pursuit of music appreciation and habits are also to the national music put forward new requirements, because the world of art is that coincide with the times, to fully tap the Chinese music and cultural heritage, enriching the content of national music art. China must be correct positioning national folk music, traditional and popular music, folk art resources are introduced, highlight the school characteristics. In the process of curriculum reform, reasonable arrangement of courses, reform education method;Use of local resources, giving play to the role of education to cultivate and promote the national folk music.

\section{References}

[1] T. M. Liu, The study of the Chinese music forms in the 1990's, Music and performance, 2005, vol. (3),pp. 13-17.

[2] D. W. Cheng, Research on multimedia auxiliary teaching, Multimedia technology and its application, 2012,vol. (3), pp. 25-28.

[3] T. K. Shen, Some questions about ethnomusicology, Chinese music, 2010, vol. (7), pp. 16-19.

[4] W. L. Zhou, The application research of national wind in music education, The application of Qinghai social science, 2012, vol. (4), pp. 6-11.

[5] B. Y. Jia, China's music education, Journal of Chinesemusic and dance, 2013, vol. (11), pp. 54-57.

[6] D.F. Ma, The theory of Chinese school music education reform,Music research, 2011, vol. (2), pp. 45-49. 